\title{
Shareholders' Preference and Dividend Policy: An Empirical Analysis of Listed Industrial Goods Companies in Nigeria
}

\author{
Aishat Salawudeen ${ }^{1} \quad$ Muhammad Aminu, Isa ${ }^{2}$ Moshoud Yinka Salaudeen ${ }^{1}$ \\ 1.Faculty of Management Sciences, University of Abuja, P.M.B 117, Abuja- Nigeria \\ 2.Faculty of Social and Management Sciences, Bayero University Kano, P.M.B.3011, Kano - Nigeria
}

\begin{abstract}
Corporations pay various types of dividend understanding that shareholders belong to a particular group or clientele and prefer a particular policy that suits their purpose. This study investigates cash and stock dividend preferences on dividend per share of listed industrial goods companies in Nigeria using mixed-method research. Sample data were extracted from the Nigerian Stock Exchange (NSC) for a period of twelve years from 2007 to 2018 and a survey research design was adopted for data relating to shareholders' dividend preference as responses were sought from shareholders through questionnaire means. OLS regression analysis was adopted to estimate the two constructs. The result supports bird in the hand theory as a cash dividend, Leverage, and size has a positive significant effect on dividend per share. However, capital gained has negative insignificant, and return on equity has a positive insignificant effect on dividend policy of listed industrial goods companies in Nigeria. This study suggests that cash dividend should be given more priority as a way of boosting the shareholders' confidence. Also, reasonable outside funds should be maintained to enable diversification as this can boost the profitability of the firms as well as the cash returns to shareholders. These results provide empirical justification for the current economic meltdown in Nigeria as most shareholders' bought sock at high rates which is currently selling at a lower price. To get value on such stock, shareholders will prefer cash dividend because cash dividend is the only way they can get cash from their investment without having to sell off their stocks.
\end{abstract}

Keywords: Bird-in-the-Hand, Cash dividend, Capital gained, Clientele effect, OLS, Snowball Sample method.

DOI: $10.7176 /$ RJFA/11-24-08

Publication date: December $31^{\text {st }} 2020$

\section{Introduction}

Corporate dividend decision is one important financial decision of the management around the globe. There is a consensus amongst financial researchers that no single factor affects corporate dividend decisions as the results of researches in this area are not directional. Attempt to solve the paradox of why firms pay dividends? What factors determine dividend payment and why investors prefer firms that pay dividends has been inconclusive. While some studies such as Franco (2004) and Papadopoulos and Dbmitrios (2007) and Musa (2009) established the reasons why firms pay dividends irrespective of tax and other circumstances. Adelagan (2003) and Fahim, Khurshid and Tahir (2015) on the other hand examine the factors that determine dividend payment. However, theorists such as Gordon and Shapiro (1956), Lintner (1956), and Bechmann and Raaballe (2007) have explained the relationship between shareholders' dividend preference and dividend policy and provides support for the bird-in-the-hand theory. Though, Graham and Dodd (1934) and Miller and Modigliani (1961) criticize the explanation and refer to it as a bird-in-the-hand fallacy. On one hand, Litzenberger and Ramaswamy (1979) supported tax preference explanation and argued that investors attracted to firms that have dividend policies appropriate to their particular tax circumstances. The investors may prefer lower payout companies for tax reasons. On the other hand, Papaioannous and Savarese (1994) could not find support for tax explanation. However, financial literature on dividends assumes that managers are perfect agents of investors, and it seeks to determine why these agents pay dividends (Easterbrook, 1984). Other literature is about the firms, usually assumption that managers are imperfect agents and inquire how managers' interests may be aligned with shareholders' interests because the two lines of inquiries are rarely met.

More so, in theory, different types of dividend policies exist in both developed and developing countries of the world. This is because shareholders are seen to belong to a particular group or clientele, they tend to prefer a particular policy that might suit them, Franco (2004) refer to this phenomenon as clientele effect of dividend policy. Nevertheless, there is a significant difference between dividend policies in practice and the shareholder's dividend preferences in reality especially in developing countries of the world like Nigeria. Hence, the need to empirically investigate the relationship between shareholders' dividend preferences on the dividend policy of listed industrial goods companies in Nigeria. Thus, an investigation on the issues of shareholders' dividend preference and dividend policy is an important one.

Furthermore, there is the dearth of studies that specifically investigates issues on shareholder's dividend preferences and dividend policy. Except for studies by Brennan and Thakor (1990) which examine shareholder's preference on dividend policy and Gang and Jason (2009) which examine equity ownership, shareholders' preference, and dividend policy in China. The possible ways in which shareholder's dividend preferences follow 
the same track of dividend policy is an important question that triggers this research. Hence, the main objective of this study is to examine whether shareholder's dividend preferences relate to the dividend policy of listed industrial goods companies in Nigeria. This study contributes to the existing literature on the subject matter and it provides empirical evidence on the subject matter as the study revealed that the cash dividend is significantly and positively related to dividend policy measures. Practically, this study would be useful in formulating financial policies. This is because governing bodies through its legal system have well-established rules and regulations that have given shareholders the power to force companies to distribute cash dividend. It is usually the responsibility of the government to enact and ensure enforcement of legal rules concerning dividends. The rest of the paper is organized into four sections as follows. Section two reviews the relevant existing literature and provides the theoretical framework of the study. Section three discusses the methodology of the study. Section four presents the results of the analyses and discussion while the last section concludes the study and presents recommendations.

\section{Review of Related Literature and Hypotheses Development}

\subsection{Dividend Policy}

Miller and Modigliani (1961) propose the irrelevance of dividend policy with a view of a world without taxes, transaction costs, or other market imperfections. Pandey (1999) gave a summary of Miller and Modigliani's theory as Perfect capital markets. That the firm operates in perfect capital markets where investors behave rationally, information is freely available to all, there are neither taxes (nor differences in tax rates applicable to capital gains and dividends) nor brokerage fees, and no single participant can affect the market price of the security through his or her trades. Homogeneous expectations. All individuals have the same beliefs. There is, therefore, no risk of uncertainty and one discount rate is appropriate for all securities and all periods. The investment and borrowing of firms are set ahead of time and are not altered by changes in dividend policy. Following these assumptions, they argue that the shareholders' value depends on the firm's earnings which results from its investment policy and not how the earnings are split between dividend payout and retention. Thus, for firms operating under perfect market conditions, they must face at least one of these three situations regarding dividend payment: a) the firm has sufficient cash to pay dividends. b) firms do not have sufficient cash to pay dividends and therefore issues new shares to finance the dividend payment and c) the firms do not pay a dividend. Since shareholders receive cash when dividends are paid by a firm. The firm's cash account will have to be credited to reduce the firm's cash balance. So, shareholder's gain of the cash dividend will decline the firm's cash balance. In such a case, there exists a transfer of wealth from firm to shareholders. Hence, there is no net gain or loss. Since it is a fair deal under the perfect capital market, the value of the firm will remain the same. Black and Scholes (1974) and Miller and Scholes (1978) provide support to dividend irrelevance theory and contend that the irrelevance theory work even when MM's assumptions are relaxed.

However, Zafar, Chaubey, and Khalid (2012) state that dividends are lawful protection of shareholders consequently the adoption of dividend policies and payment of dividend to shareholders, who are ultimate owners of the company are entitled under Companies and Allied Matters, Act 2004 (CAMA) Section 379 (5) which states that dividends shall be payable to the shareholders only out of the distributable profits of the company. Accordingly, the decision to pay dividends and at what amount is determined based on the company's excess cash, and it is usually influenced by the company's long-term profitability. Therefore, dividend policy can be defined as a set of guidelines a company practice to decide how much of its earnings will be paid out to shareholders. Dividend policy is also defined as financial policies regarding the payment of cash dividend in the present or pay an increased dividend at a later stage. In a similar vein, Rahman (2015) defined dividend policy as a deliberate action of managers to distribute a portion of earnings to shareholders in proportion of their holdings. The dividend policy of the company generally determines the division of cash reserves generated through efficient overall performance between payments to shareholders and reinvestment in the firms through retention (Zafar, Chaubey \& Khalid, 2012). Dividend decisions are one of the important financial decisions because the role of finance has increased significantly on the overall growth of the company as suggested by Rahman (2015) as such dividend decision is one of the top ten complex issues in finance (McNicholas, \& David, 1990). The dividend policy is to decide on the number of earnings to be distributed as dividend and the amount to be retained by the company.

\subsection{Dividends per share}

Dividends per share is an accounting ratio used to evaluate the total number of dividends declared for each share of the issued stock, the issued stock is common stock. Therefore, declared dividends are the percentage of the firm's income that is to be given to the shareholder as a return on their investment. Conversely, declared dividends are not to be taken as the equivalent of paid dividends. The amount that is not paid to the shareholders is considered retained earnings. In a nutshell, dividends per share are important because it shows returns to the shareholders. Shareholders care about the amount of dividend per share because dividends make ways for financial return after buying shares of a company. Shareholders use dividend per share ratio to analyze the financial capabilities of the company. Dividends per share only account for dividends that are to be distributed regularly, rather than one-time 
payments to shareholders. Studies such as Huda and Abdullah (2014) and Alias, Rahim, Nor, and Yaacob (2013) have proven dividend per share as a good determinant of dividend policy.

\subsection{Cash Dividend}

Paying cash dividend is better than companies retaining earnings for growing business. Perhaps, because the dividend is considered as the only way shareholders can collect cash from their stock investments without having to sell them. This is on the premises that capital gained is full of uncertainty as companies may eventually collapse and investors get nothing, so it is preferable to get the money first rather than capital gains which are more risky and uncertain, as such investors would expect to be compensated with higher returns by mounting pressure on the management to deliver advanced future growth, which may or may not be attained. Consequently, the cost of holding retained earnings is higher than distributing it away and this makes companies prefer distributing some percentage of it earning as dividends to shareholders (Allen, Bernardo, \& Welch, 2000). The purpose of this argument could be defeated if a lack of dividends places money invested at intolerable risk, when shares price fall in the market upon a no-dividend payment than otherwise, and this can render investors poorer and hopeless than they would ordinarily be if reasonable dividends are returned to the shareholders. Rahman (2015), Gang and Jason (2009) and Brennen and Thakor (1990) provide support for a cash dividend. They argue that despite the preferential tax treatment of capital gained for individual investors, a majority of investors may prefer dividend payment for a small distribution. Walter (1963) argues that dividend policy affects the value of firms by modeling the relationship between a firm's rate of return and its cost of capital in determining the dividend policy that will maximize the value of the shareholders. Gordon's model is based on assumptions that are similar to Walter's model. The empirical literature has appeared to support the dividend relevance theory in and around the globe. These studies include Lakonishok and Lev (1987), Brennan and Thakor (1990), and the later works of Bechmann and Raaballe (2007), and Musa (2009) provide substantial support to the view that dividend policy affects shareholders interest. Given these conditions, shareholder's dividend preferences should affect dividend policy. Thus,

Hypothesis 1 cash dividend does not relate to the dividend per share of listed industrial goods companies in Nigeria.

\subsection{Capital Gained}

Stock dividends assist firms towards capitalizing their retained earnings into their stock accounts, although do not provide a distribution of accumulated wealth to shareholders. Accordingly, stock dividends have no direct impact on cash flow, in the absence of an indirect influence on cash flow, there should be no impact on stock prices once there is a stock dividend announcement (McNichols \& Dravid, 1990 and Murray, 1985). Nonetheless, researchers such as Chen, Chan, and Steiner (2002) and Lakonishok and Lev (1987) have reported positive abnormal returns around announcements of stock dividends. Scholars such as Brealey, Myers, and Allen (2006), Ross, Westerfield, and Jaffe (2005), Black (1976), etc. have proven several hypotheses to explain why firms distribute stock dividends to shareholders. Black (1976) concludes that corporations are the only investors with a tax preference for dividends, a view that is now widely accepted. Ross, Westerfield, and Jaffe (2005), for instance, write that corporations prefer to invest in high-dividend stocks, even without a preference for current income. Brealey, Myers, and Allen (2006) similarly write that only corporations have a tax reason to prefer dividends. Empirical studies such as Morgan (1982) and Blume (1980) on the tax preference theory have lent support though contradictory to the tax preference theory. Their studies reveal that high-yielding stocks have lower prices and offer higher returns. Though, Miller and Scholes (1978) stressed the difficulties of measuring dividend yield properly and proving the link between dividend yield and expected returns. In any case, Chen, Chan, and Steiner (2002) support the hypothesis that the lower the taxes, the higher the payout. Also in supports of this view is Jang (1994) while Papioannous and Savarese's (1994) results contradict the result of Jang. Given these conditions, shareholder's dividend preferences should affect dividend policy. Thus,

Hypothesis 2 capital gained (stock dividend) does not relate to the dividend per share of listed industrial goods companies in Nigeria.

\subsection{Review of Empirical Studies}

Haque, Fuad, and Mahamud (2017) explore the investor preferences for capital gained and dividend payment in Bangladesh. The study used a questionnaire to solicit information from the shareholders on their dividend preference style. The results show that overall, investors prefer capital gain over cash dividend. The results from the regression also demonstrate that all demographic variables and investor characteristics, specifically education level, age, investment amount, and investment income, are positively related to investors tend to prefer dividend payment, with investment income and age having the strongest impact. The results of this test reconfirm that investors with larger sums tend to be more risk-averse. Moreover, the results from the primary data also reveal that investor preferences are compatible and consistent with traditional theories including the Birds-in-the-Hand Theory, Information Signaling Theory, Tax Preference Theory, and Clientele Effect Theory. 
Rahman (2015) examines the managers' perception towards dividends and the Dividend Policy of companies listed on the Dhaka Stock Exchange (DSE) of Bangladesh. The study engaged a practical survey on the perception of managers of twenty-four companies to test the behavior of Bangladeshi listed firms towards dividend payout policy using different dividend theories. The result of the investigation reveals that the bird-in-hand theory and the relevant value theory were mostly supported.

Barasa (2014) examines the effects of investment appraisal methods on shareholders' wealth in Kenya. Pilot testing of the data collection tools was done.it helped identify weaknesses in the data collection tools piloting was done using 10 respondents randomly selected from the 57 firms listed in the Nairobi Security Exchange. The instruments that were used in this study were majorly secondary data and semi-structured questionnaires. The findings of the study indicated that there was a positive relationship between asset allocation and shareholders' wealth in the years between the years 2009 to 2013. There was a positive relationship between market timing in stock and shareholders' wealth in the years between the years 2009 to 2013 in Nairobi securities exchange. The findings of the study indicated that asset allocation and market timing investment methods influenced shareholder wealth positively when other factors were kept constant.

Brav, Graham, Harvey, and Michaely (2005) explain that managers tend to make dividend policy decisions that are unlikely to be reversed in the future. Their study found that the present year's dividend payout will not be based on the present year's earnings; however, it can impact next year's earnings. Brav, Graham, Harvey, and Michaely (2005) support the study of Marsh and Merton (1987) who note that managers emphasize more on the change in dividend instead of the change in the absolute dividend.

La Porta, Lopez-De-Silanes, Shleiffer, and Vishny (2000) test on a cross-section of 4,000 firms in 33 countries across the world and find that countries with stronger legal protection of minority shareholder rights are associated with higher dividend payout because minority shareholders pressure corporate insiders to pay dividends. They found that fast-growth companies typically pay lower dividends than high growth companies, indicating that investors are willing to wait for good dividends. Also, concluded that differential tax treatments were shown to alter an investor's preference of dividend because this will ultimately affect the after-tax return. Deeptee and Roshan (2009) mention that firms must pay high enough dividends to avoid smaller firms from being able to replicate the strategy. This would also ensure that the larger firms have a higher stock price. However, extending the argument of Marsh and Merton (1987), having a higher dividend rate also means that if the company for any reason decides to lower the dividend rate, it will likely suffer from a share price drop.

Palmer (1994) investigate whether private investors regard dividends as important (to themselves personally or as a signal of the company's performance) and also how dividends impact upon a company's value. A survey of 280 private investors tested these questions and concluded that private investors believe that dividends do affect the value of a share, dividends were perceived to be a safer form of income (but capital gains is preferred), that dividend increases and decreases occur because of different reasons (mostly related to profitability or liquidity) and that an aging clientele does exist. Most significantly, this analysis revealed that investors behave in a way best described by Lintner's view of dividend policy, as they: prefer higher dividends to lower dividends, believe dividends are a safer form of income, and believe that dividends affect the value of a share.

Brennan and Thakor (1990) examine shareholders' preferences and dividend policy. The paper develops a theory or choice among alternative procedures for distributing cash from corporations to shareholders. Despite the preferential tax treatment of capital gains for individual investors, the finding showed that a majority of a firm's shareholders may support a dividend payment for small distributions. Baker, Edelman, and Ferrelly (1983) analyses the dividend policy in light of various theories on how dividends affect stock prices in Texas. The study used a questionnaire to examine the information from the shareholders on their dividend preference style. The sample consisted of financial executives of 605 firms in three industry groups: manufacturing, utilities, and retailwholesale. The three groups showed considerable homogeneity in the overall ranking of factors and issues relating to dividend policy but have distinct differences in specific items. The evidence indicates that firms base their dividend policy decisions on numerous factors, the most important being the anticipated level of future earnings and the pattern of past dividends. This was extended by LeRoy (2007) who concluded that the theory applies even in the presence of taxes when dividend tax rates and capital gains are equal. Moreover, when capital gains tax is lower than the tax on dividend, share repurchases have the same effect as allocating funds for new investments.

\section{Methodology}

This study adopted a mixed research design. Ex-post facto research design and survey design. Information on dividend policy was collected from annual reports and accounts of sampled industrial goods companies for twelve years (2007-2018). Twelve year period is considered suitable for the study to generate adequate data. Also, the time frame is considered suitable because most prior studies on shareholders' dividend preference and dividend policy used twelve years to empirically review the relationship between shareholders' dividend preference and dividend policy. Ex-post facto research design is considered appropriate for this study because the phenomena of the study had already taken place and the data to be used are in existence. On the other hand, a survey research 
design was adopted for data relating to shareholders' dividend preference. As responses were sought shareholders through questionnaire means. These methods are selected to enable the researcher to understand the shareholders' preferences for dividend payment.

The study used two sets of populations. The definite population of fifteen (14) listed industrial goods companies in the Nigerian Stock Exchange as at $31^{\text {st }}$ December 2018, this sample size was arrived at using the filter to eliminate some of the firms that were considered unsuitable for the study. Only companies that have filed their published audited financial statements with the Nigerian Stock Exchange (NSE) for the entire period were selected. Also, the indefinite population of shareholders of listed industrial goods companies, judgmental sampling technique was used to select eleven (11) shareholders from an indefinite number of shareholders of listed industrial goods companies and snowball sampling method, a non-probability sampling technique was used to recruit future subjects from among their acquaintances of the eleven shareholders. This technique is informed by the previous such as Krejcie \& Morgan (1970) who proposed the population proportion of 0.05 as adequate to provide the maximum sample size required for generalization.

\subsection{The Instrument of Data Collection}

The instrument for data collection is a questionnaire designed on 5 points Likert scale and administered to the shareholders of listed industrial goods companies on the Nigerian stock exchange from 2007 to 2018 . The targeted shareholder will cut across all types. The rationale for using self-administered questionnaires is to allow the respondents to answer at their own pace without any form of inconveniences. The respondents had to indicate whether they strongly disagree 1 , disagree 2 , are neutral 3, agree 4, or strongly agree 5 to the question posed. The questionnaire will be in three sections. Segment A will capture demographic information about respondents. Information such as age, education qualification, work experience, shareholders type. Segment B will capture information on the shareholders' preferences for a cash dividend. Segment $\mathrm{C}$ will capture information on the shareholders' preferences for capital gain.

3.2 Internal Reliability Test

This test reliability of the data of the using Cronbach's alpha. Cronbach's alpha is used to measure internal consistency that is the reliability of the information in use. As the instrument of data collection is multiple Likert questions in a survey questionnaire.

Table 3.1 Variables and Operationalization

\begin{tabular}{|c|c|}
\hline Variables & Operationalization \\
\hline \multicolumn{2}{|r|}{ Dependent Variables } \\
\hline Dividend per Share & $\begin{array}{l}\text { Dividend per Share is calculated as the dividend is divided by the number of } \\
\text { shareholders outstanding as used by Huda and Abdullah (2004) and Alias, } \\
\text { Rahim, Nor and Yaacob (2013) }\end{array}$ \\
\hline \multicolumn{2}{|r|}{ Independent Variables } \\
\hline Cash Dividend (CD) & $\begin{array}{l}\text { Amount of cash dividend payment to shareholders in line with the study of } \\
\text { Rahman (2015), Gang and Jason (2009) and Brennen and Thakor (1990) }\end{array}$ \\
\hline Capital Gained (CG) & $\begin{array}{l}\text { Stock dividend payment to shareholders in line with the study of Rahman } \\
\text { (2015) and Gang and Jason (2009) }\end{array}$ \\
\hline \multicolumn{2}{|r|}{ Control Variables } \\
\hline Return on Equity (ROE) & $\begin{array}{l}\text { Net Profit/ Shareholder equity as used by Huda and Abdullah (2004) and } \\
\text { Ali-Sha, Ullah, \& Hasnain (2011) }\end{array}$ \\
\hline Leverage (LEV) & $\begin{array}{l}\text { Leverage is measured by total debt divided by total assets as used by } \\
\text { Abdulrahaman and Salawudeen (2017), Huda \& Abdullah (2004) and Alias, } \\
\text { Rahim, Nor and Yaacob (2013) }\end{array}$ \\
\hline Firm Size (FS) & $\begin{array}{l}\text { Firm Size is measured by the natural log of total assets as used by Huda and } \\
\text { Abdullah (2004), }\end{array}$ \\
\hline
\end{tabular}

3.3 Model Specification

$D P S_{i t}=f(C D, C G, L E V, R O E$, and FS $)$

$D P S_{i t}=\alpha_{0}+\beta_{1} C D_{i t}+\beta_{2} C G_{i t}+\beta_{3} L E V_{i t}+\beta_{4} F S_{i t}+\beta_{5} R O E_{i t}+\mu_{i t}$

Where

DPS

$\mathrm{CD}$

CG

LEV

FS

ROE
Dividend per Share for Firm i in Period t,

Cash Dividend for Firm i in Period t,

Capital Gained for Firm i in Period t,

Leverage for Firm i in Period t,

Firm Size for Firm i in Period t,

Return on Equity for Firm i in Period $t$ 


\section{Results and Discussions}

This section first presents data relating to the questionnaires under the primary sources of data which were distributed to eleven shareholders each of industrial goods companies in Nigeria.

\subsection{Administration and Return of Questionnaires}

Out of one hundred and fifty-four questionnaires distributed, one hundred and twenty questionnaires were filled and returned. However, ten questionnaires not properly filled, and thirty-four of the questionnaires not returned as such were excluded from the sample. Hence one hundred and ten responses were extracted as data regarding shareholders' dividend policy.

Table 4.1 Shareholders Category of the Returned Questionnaires

\begin{tabular}{|l|l|l|l|l|}
\hline $\begin{array}{l}\text { No. } \\
\text { questionnaires }\end{array}$ & $\begin{array}{l}\text { Individual } \\
\text { Shareholders }\end{array}$ & $\begin{array}{l}\text { Managerial } \\
\text { Shareholders }\end{array}$ & $\begin{array}{l}\text { Institutional } \\
\text { Shareholders }\end{array}$ & Total \\
\hline 120 & 90 & 8 & 22 & 120 \\
\hline
\end{tabular}

Source: Computation from the Returned questionnaires

Table 2 shows that out of the total number of one hundred and twenty properly filled and returned questionnaires, ninety were from individual shareholders, eight from managerial shareholders while twenty-two were returned by the institutional shareholders. Data was collected using a convenience sampling method from retail investors. Institutional investors are excluded from this survey. The main reason for this exclusion of institutional investors is the probability of non-representative reflection of investor's preference. If institutional investors like investment funds, mutual funds act as replacements of their clients, their portfolio decisions may reflect the preferences of their clients because the income flows directly to the beneficiary owners. This study, therefore, includes only those investors who are directly invested in the market.

\subsection{Reliability Test}

The various responses to the research questions as contained in the Likert scaled questionnaires were first subjected to internal consistency checks to ascertain the reliability of the data using Cronbach alpha, then an average of the responses was taken and regressed against the dependent variable.

Table 4.2 Cronbach Alpha

\begin{tabular}{|l|l|l|l|}
\hline Variable Name & No. of Items & Average Inter-item covariance & Scale Reliability Coefficient \\
\hline Cash dividend & 14 & 0.6308 & 0.8973 \\
Capital gained & 10 & 0.2930 & 0.8401 \\
\hline
\end{tabular}

Source: Computation using STATA 13.0

This result is satisfactory as the two objectives' scale reliability coefficient was 0.89 and 0.84 respectively. Cronbach (1951) suggests that a high value of alpha was 'desirable' when an instrument was used to assign a score to an individual, but he stressed that scores obtained when using an instrument should be interpretable. Therefore the internal consistency is reliable.

\subsection{Robustness Check}

Robustness test was carried out to ensure the validity of all statistical inferences for this study and also to check the problems of outliers of the data collected before the choice of an appropriate statistical method to use. The linearity test was conducted to check the relationships between the variable, it does provide good testing for linearity. Multicollinearity test was carried out to ascertain whether two or more independent variable is interrelated. The result reveals an insignificant dependency amongst the variables in the study. To determine the presence of collinearity problem, a Variance Inflation Factor (VIF) test was conducted with a mean of 1.06 (see table 6) which is less than 10 benchmark for acceptance, this result provides evidence of the absence of collinearity. The heteroscedasticity test was further conducted to ascertain whether the variability of the error term is constant or not. The result implies that the variability of the error term is not constant as the coefficient of 5.40 with its significant value of 0.02 . A heteroscedasticity robust standard error test was conducted to correct that. Normality of residuals was also carried out to ensure that the validity of all tests ( $\mathrm{p}, \mathrm{t}$, and $\mathrm{F}$ ) residuals behave normally. However, the study predicts error term (e) by running test e and the result reveals insignificant p-value at 0.3026 which means that the standard error is normally distributed. 
4.4 Descriptive Statistics

Table 4.3 Descriptive Statistics of Shareholders' Preference and Dividend Policy

\begin{tabular}{llcccccc}
\hline Variable & Obs & Mean & Std. dev. & Min & Max & Skewness & Kurtosis \\
DPS & 110 & 0.2355 & 0.1968 & 0.0079 & 1.0239 & 0.0000 & 0.0000 \\
CD & 110 & 3.6818 & 1.0999 & 1 & 5 & 0.0276 & 0.0974 \\
CG & 110 & 3.8545 & 0.9466 & 1 & 5 & 0.0042 & 0.8694 \\
LEV & 110 & -0.101 & 0.6559 & -2.763 & 1.1172 & 0.0000 & 0.0000 \\
ROE & 110 & 0.2520 & 0.2828 & 0.0102 & 0.9843 & 0.0001 & 0.8436 \\
SIZE & 110 & 7.2709 & 0.6789 & 4.9993 & 8.4475 & 0.0002 & 0.0320 \\
\hline
\end{tabular}

Source: Computation using STATA 13.0

The average returns to the shareholders for all the sampled industrial companies in Nigeria over ten year period is N0.24k indicating regular financial returns to the shareholders after buying shares. The standard deviation of 0.19 implies that there is no significant variation in Dividend per Share amongst the sampled firms during the period of study. The minimum value of dividend per share is $\mathrm{N} 0.007 \mathrm{~K}$ implying low dividend payment in some companies during the period of study with a maximum of N1.02k.More so, the mean of the capital gained of the study sampled is 2.68 , meaning that the majority of the shareholders do not consent to the stock dividend as a form of return to shareholders. The standard deviation of 1.09 indicates that there is no significant deviation among the respondents. The minimum value is one while the maximum of five. Likewise, the mean of the cash dividend of the study sampled is 3.85 , meaning that the majority of the shareholders do consent to cash dividend as a form of return to shareholders. The standard deviation of 0.95 indicates that there is no significant variation among the responses. The minimum value is one while the maximum of five.

\subsection{Correlation Analysis}

Table 4.4 Correlation Matrix of Shareholders' Preference and Dividend policy

\begin{tabular}{lccccccc}
\hline Variables & DPS & CD & CG & LEV & ROE & FS & VIF \\
DPS & 1.0000 & & & & & \\
CD & 0.0041 & 1.0000 & & & & 1.03 \\
CG & 0.1359 & -0.037 & 1.0000 & & & 1.06 \\
LEV & -0.096 & 0.1006 & -0.118 & 1.0000 & & 1.11 \\
ROE & 0.1687 & -0.108 & -0.068 & -0.199 & 1.0000 & 1.09 \\
SIZE & 0.4875 & 0.0839 & -.0034 & -.0175 & 0.0306 & 1.0000 & 1.03 \\
\hline \multicolumn{8}{c}{ Source: Computation using STATA 13.0} \\
\end{tabular}

This shows the results of the Spearman rank correlation between the dependent variable (DPS) and explanatory variables (CG, CD, ROE, LEV, and FS). The use of Spearman rank correlation was suggested by the p-values of the pre-estimation tests-skewness and kurtosis. The relationship between CG and ROE to DPS is weak and negative at the correlation coefficient value of $-0.18-0.004$, and -0.096 respectively. However, CD, LEV, and FS have a positive but weak relationship with DPS at the values of $0.14,0.17$, and 0.49 respectively. This study further explains the relationship between one independent variable and another. CD and LEV are negatively correlated to CG at the values -0.04 and -0.11 . But ROE and SIZE have a positive relationship with the CG at the value of 0.10 and 0.08 respectively. The relationship between ROE, LEV, and SIZE to CD is weak and negative at the value $-0.12,-0.07$, and -0.03 respectively. While LEV and SIZE have a weak and negative relationship with ROE at the valves of -0.20 and -0.18 . Again SIZE has a positive but weak relationship with LEV at the value of 0.03 . The VIF indicates no present of Multicollinearity in the data used for the study.

4.6 Regression Analysis 
Table 4.5 OLS Regression Result of Shareholders' Dividend Preferences and Dividend Policy

\begin{tabular}{llll}
\hline Variables & Coefficient & t-value & Sig \\
\hline Constant & -07020 & -3.50 & $0.001^{* * *}$ \\
CG & -0.0002 & -0.02 & 0.987 \\
CD & 0.0320 & 1.74 & $0.085^{*}$ \\
ROE & 0.0239 & 0.88 & 0.383 \\
LEV & 0.1435 & 2.24 & $0.027^{* *}$ \\
SIZE & 0.1075 & 4.18 & $0.001^{* * *}$ \\
\hline $\mathrm{R}^{2}$ & 0.20 & & \\
Adj. $\mathrm{R}^{2}$ & 0.17 & & \\
Obs & 110 & & \\
F(sig) & 5.48 & & \\
Prob $>$ F & $0.0002 * * *$ & & \\
VIF mean & 1.06 & & \\
Hottest chi & 7.37 & & \\
Hettest Prob $>$ chi $^{2}$ & $0.0066^{*}$ & & \\
Sktest & 2.39 & & \\
Sktest Prob $>$ chi $^{2}$ & 0.3026 & & \\
\hline
\end{tabular}

Source: Computation using STATA 13.

Where $* * *, * * *$ indicate significance levels at $10 \%, 5 \% \& 1 \%$ respectively.

Table 6 shows the OLS regression result of shareholders' dividend preferences and dividend policy. The pvalue of the model of 0.0002 shows that the relationship between shareholders' dividend preferences and dividend policy of the sampled firms is statistically significant. R-square shows 0.21 . This means that the overall relationship between the two constructs is $21 \%$. Adj $\mathrm{R}^{2}$ is $17 \%$ of the variation in dividend policy that is explained by the explanatory variables capital gained (CG), cash dividend (CD), return on equity (ROE), leverage (LEV), and firms size (FS). The remaining $83 \%$ of the total variation in the dividend per share and explanatory variables are caused by factors not captured in the model. The result of OLS regression shows that the effect of cash dividend, leverage, and firm size on dividend per share is positive and has $10 \%, 5 \%$, and $1 \%$ level of significance respectively. Moreover, capital gained to have a negative insignificant relationship on dividend policy. While return on equity has positive but no significant effect on dividend policy of the study samples.

The cash dividend has a positive effect on dividend per share which indicates that shareholders of the sampled firm preferred cash dividend than capital gained. This implies that an increase in dividend per share will be welcomed by the shareholders of the sampled firm. An increase in dividend per share increases the shareholders' dividend preferences by $8.5 \%$ of the sample firms. The apriori expectation of the effect of a cash dividend on dividend per share is that it has a positive effect as literature backing by Gordon (1963) and Lintner (1956) predicts that the shareholders will prefer cash of one naira worth today than a future risk of two nairas because rational investors prefer to invest in stocks that pay high and stable dividends. This result confirms the existing literature on this phenomenon. For example, the studies of Rahman (2015), Gang and Jason (2009), and Brennen and Thakor (1990) establish a positive significant relationship between the two constructs. Earlier, it was hypothesized that the cash dividend does not relate to the dividend per share of listed industrial companies in Nigeria. The null hypothesis was estimated using regression analysis. The magnitude of the effect of a cash dividend on dividend per share indicates a coefficient and t-value of 0.0320 and 1.74 respectively with significant value at 0.085 meaning that cash dividend has a positive significant influence on dividend per share. Subsequently, the relationship is statistically significant, thus, we reject the null hypothesis that the cash dividend does not relate to the dividend per share and concludes that there is a significant positive influence of cash dividend on dividend per share of listed industrial companies in Nigeria. A significant positive effect of a cash dividend on dividend per share indicates shareholders' preferences for cash dividend as against capital gained which implies the need to encourage an effective financial decision process, especially dividend policy in the sampled companies.

However, Capital gained is found to have negative but insignificantly influence on dividend per share meaning that capital gained does not determine the dividend policy of the sampled firm. The apriori expectation of the effect of capital gains on dividend per share is that it has a positive effect as literature backing by Bradford and Gordon (1980), Blume (1980), Morgan (1982), Black (1976) and Blough and Hewett (1938) predicts in consideration to tax, that firms may prefer to distribute stock dividends to shareholders when taxes on dividend income is high. This result contradicts the existing literature on this phenomenon. For example, the studies of LeRoy (2007) concluded when capital gains tax is lower than the tax on dividend, share repurchases have the same effect as allocating funds for new investments. Earlier, it was hypothesized that the capital gains does not relate to the dividend per share of listed industrial companies in Nigeria. The null hypothesis was estimated using regression analysis. The magnitude of the effect of capital gains on dividend per share indicates a coefficient and t-value of 0.0002 and -0.02 respectively with significant value at 0.987 meaning that capital gains have a negative 
insignificant effect on dividend per share. Subsequently, the relationship is statistically insignificant, thus, we accept the null hypothesis that the capital gained does not relate to the dividend per share and concludes that capital gained does not influence dividend per share of listed industrial companies in Nigeria. An insignificant negative influence of capital gained on dividend per share indicates shareholders have no preferences for capital gained which implies the need to encourage an effective financial decision process, especially dividend policy in the sampled companies. We accept the null hypothesis that the capital gain does not affect the dividend policy of the sampled firm.

The study controlled for return on equity, leverage, and firm size. While return on equity has a positive insignificant relationship with dividend per share. This indicates that profitability is not an indication of whether a firm pay dividend or not in the sampled firms. However, leverage has a positive significant effect on dividend per share. This indicates that an increase in leverage can increase the dividend per share by $1 \%$. This implies that highly levered firms do affect the number of returns to shareholders as a dividend because the more external fund is injected into the business to meet the needs for viable projects capable of yielding a profit that enables management to give more return to the shareholders of the sampled firms. This result contradicts the result of Huda and Abdullah (2014) who found a negative significant relationship between the two constructs and the study of Abdulrahaman and Salawudeen (2017) who found a negative insignificant effect. We reject the null hypothesis that leverage has no significant effect on dividend per share of sampled firms in Nigeria. Firm size also indicates a significant relationship with the dividend per share of sampled firms. Indicating that, the larger the firm, the more likely they pay a dividend. This result is contrary to the findings of Huda and Abdullah (2014) who found an insignificant association between the two constructs. Base on the finding we reject the null hypothesis that the size of the sampled firm has a significant effect on dividend per share.

\section{Conclusion and Recommendation}

This study concludes that there is a significant positive relationship between cash dividend preferences with the dividend per share of sampled industrial goods companies in Nigeria. This implies that an increase in dividend per share does influence the shareholders' cash dividend preference as such cash dividend can be a significant determinant of dividend policy in the sampled firm in Nigeria. This means that an increase in cash dividend as against other forms of dividend will be welcomed by the shareholders of the sampled firm as the dividend is the only way shareholders can get cash on their investment without having to sell off the shares. Also, leverage and size have a positive significant influence on dividend per share. This mean levered and older firms are most likely to have high dividend per share because of the availability of fund to embark on profitable projects which means more income for the shareholders. However, capital gained and return on equity have a negative and positive insignificant effect on dividend per share respectively. This implies that both capitals gained and return on equity do not affect the dividend policy of the sampled firm.

It's recommended that the cash dividend should be given more priority when considering the dividend policy of sampled firms in Nigeria. As the shareholders tend to favor bird-in-the-hand theory. Also, a reasonable outside fund should be maintained as this can boost the profitability of the firms which in turn boosts the cash returns to shareholders.

\section{References}

Adelegan, O. J. (2003), “An Empirical Analysis of the Relationship between Cash Flow and Dividend Changes in Nigeria”, African Development Review, 15 (1), 35-49.

Abdullah, S. N. (2004). Board composition, CEO duality and performance among Malaysian listed companies. Corporate Governance Journal, 4(4), 47- 61.

Abdulrahaman, S. \& Salawudeen, A. (2017), "Ownership Structure, Cash Flow, and Dividend Policy: A Study of Listed Oil and Gas Industries in Nigeria", International journal of innovative research and advanced studies, 4(11), 195 - 199.

Allen, F., Bernardo, A. E. \& Welch, I. (2000), “A Theory of Dividends Based on Tax Clienteles", Journal of Finance, 55(6), 2499- 2536.

Ali-Sha, S. Z., Ullah, W. \& Hasnain, B (2011), "Impact of Ownership Structure on Dividend Policy of Firm (Evidence from Pakistan)", International Conference on E-Business, Management, and Economics, IPEDR 3, IACSIT Press, Hong Kong.

Alias, N., Abdul-Rahim, R. Nor, F. M. \& Yaacob, M. H. (2013), "Board Structure, Free Cash Flow and Dividend Per Share: Is There Interaction Effect?". 23rd International Business Research. The conference, Marriott Hotel, Melbourne, Australia, ISBN: 978-1-922069-36-8.

Bachmann. K. L. \& Raaballe, J. (2007), "The Differences Between Stock Splits and Stock Dividends: Evidence on the Retained Earnings Hypothesis", Journal of Business, Finance \& Accounting, 34 (3\&4), 574-604.

Baker, H. K., Edelman, R. B. \& Ferrelly, G. E. (1983), “Analyzing dividend policy: A questionnaire survey”, Working Paper, 83-119** 
Barasa, J. M. (2014), "Effects of Investment Appraisal Methods on Shareholders' Wealth for Companies Listed in the Nairobi Security Exchange", Journal of Business and Management, 16(10), 79-94.

Black, F. (1976), "The Dividend Puzzle", Journal of Portfolio Management, Special Issue: 5-8.

Black, F. \& Scholes, M. (1974), "The Effect of Dividend Yield and Dividend Policy on Common Stock Prices and Returns". Journal of Financial Economics, 1(1), 1-22.

Blough, R. \& Hewett W. W. (1938), "Capital Gains in Income Theory and Taxation Policy”, Chapter in NBER book Studies in Income and Wealth, volume 2, Conference on Research in National Income and Wealth, 186 $-259$.

Blume, M. F. (1980), "Stock returns and dividend yield: Some more evidence". Review of Economics and Statistics, 62(4), 567-577.

Brav, A., Harvey, C., R., Graham, J., R., and Michaely, R. (2005), "Payout Policy in the 21st Century", Tuck Contemporary Corporate Finance Issues III Conference Paper.

Brealey, R., Myers S. \& Allen, F. (2006), "Principles of Corporate Finance (8th Ed)", Irwin: Mcgraw-Hill.

Brennan, M. \& Thakor, A. (1990), "Shareholder Preferences and Dividend Policy", Journal of Finance, 45(4), 993-1017.

Chen, C. R., Chan, K. C. \& Steiner, J. 1. (2002), “Are All Security Analysis Equal?”, Journal of Financial Research, $25(3), 415-430$.

Cronbach, L. J. (1951), "Coefficient Alpha and The Internal Structure of Tests”, Psychometrika, 16(3), $297-334$. DOI: $10.1007 / \mathrm{bf02310555.}$

Easterbrook, F. H. (1984), “Two Agency-Cost Explanations of Dividends”, American Economic Review, 74(4), 650-659.

Fahim, L. Khurshid, M. K. \& Tahir, H. (2015). Determinants of Dividend Payout: Evidence from the Financial Sector of Pakistan. Journal of Poverty Investment and Development, 17(2015), 5-16.

Franco A. (2004), "Dividend Irrelevance and the Clientele Effect", Retrieved from http://www.siliconvalley.com/mld/siliconvalley/6330173.htm,

Gang, W. \& Jason, Z. (2009), "Equity Ownership Segregation, Shareholder Preferences and Dividend Policy in China", The British Accounting Review, 41(3), 169-183.

Gordon, M.J. (1963), "Optimal Investment and Financing Policy”, The Journal of Finance, 18, 264-272.

Gordon M. J. \& Shapiro, E. (1956), "Capital Equipment Analysis: The required rate of profit", Journal of Management Science, 3, 102-110.

Graham, B. \& Dodd D. L (1934), "Security Analysis: Principles and Techniques", New York: McGraw-Hill.

Huda N. \& Abdullah M. N. (2014), "Relationship between Ownership Structure and Dividend Policy: Empirical Evidence from the Chittagong Stock Exchange", World Review of Business Research, 4(3), 14-34

Haque, R., Fuad, S, M. \& Mahamud, M. S. (2017), "Dividend versus Capital Gain and Investor Preference: A Case Study on Dhaka Stock Exchange", Research Journal of Finance and Accounting 8(8), 60-68. www.iiste.org

Jensen, M. (1986). Agency costs of free cash flow, corporate finance, and takeovers. American Economic Review, 76(2), 323-329.

Jensen, M. \& Meckling, W. (1976), "Theory of the Firm: Managerial Behavior, Agency Costs, and Ownership Structure", Journal of Financial Economics, 3(4), 305-360.

Krejcie, R. V. \& Morgan, D.W. (1970), "Determining Sample Size for Research Activities", Educational and Psychological Measurement, 30, 607-610.

La Porta, R., Lopez-de-Silanes, F., Shleifer, A. and Vishny, R. W. (2000), “Agency Problems and Dividend Policies Around the World", The Journal of Finance, 55(1), 1-33.

Lakonishok, J. \& Lev, B. (1987), "Stock Dividends: Why Who and When”, Journal of Finance, 42(4), 913-932.

Linter, J. (1956), "Distribution of Incomes of Corporations among Dividends Retained Earnings and Taxes". The American Economic Review, 46(2), 97-113.

Litzenberger, R. \& Ramaswamy, K. (1979), "The Effects of Personal Taxes and Dividends on Capital Asset Prices: Theory and Empirical Evidence", Journal of Financial Economics, 7(2), 163-195.

LeRoy, S., F. (2007), "Dividend Policy and Income Taxation", USC FBE Finance Seminar.

Marsh, T. \& Merton, R., C. (1987), "Dividend Behavior for the Aggregate Stock Market”, Journal of Business, 60(1), 1-40.

Mcnicholas, M. \& David, A. (1990), “A Stock Dividend, Stock Split, and Signaling”, Journal of Finance, 45(3), 857- 879.

Miller, M. H., \& Modigliani, F. (1961), "Dividend Policy, Growth, and the Valuation of Shares", Journal of Business, 34(4), 411-433.

Miller, M. H. \& Scholes, M. S. (1978), “Dividend and Taxes”. Journal of Financial Economics”. 6, 333-364.

Morgan, I. G. (1982), "Dividends and Capital Asset Prices", Journal of Financial, 37(4), 1071-1086.

Musa, I. F. (2009), "The Dividend Policy of Firms Quoted on the Nigerian Stock Exchange: An Empirical 
Analysis". African Journal of Business Management 3(10), 555-566.

Palmer, C. G. (1994), "Dividend Policy and Private Shareholders: A New Zealand Survey", A Master Degree Thesis Submitted to the University of Canterbury.

Papadopoulos, D.L. \& Dbmitrios, P.C. (2007), "Focus on the Present Status and Determinants of Dividend Payout Policy Athens Stock Exchange in Perspective", Journal of Financial Management Analysis. 20(2), 24-37.

Papaioannous, G. \& Savarese, C. (1994), "The Corporate Dividend Policy Response to the Tax Reform Act of 1986”, Journal of Business and Financial Management, 23(4), 1-15.

Pandey I. M. (1999), "Financial Management”. Vikas Publishing House PVT Ltd., India.

Rahman, M. M. (2015), "Managers' Perception of dividends and dividend policy- Evidence from Bangladesh". Journal of Financial Risk Management, 4, 143-157. http://dx.doi.org/10.4236/jfrm.2015.43012

Ross, Westerfield \& Jaffe (2002), "Corporate Finance", Sixth Edition McGraw-Hill Primis. 10ISBN: 0-390-32000-5.

Walter, J. E. (1963), "Dividend Policy: Its Influence on the Value of the Enterprise", The Journal of American Finance Association, 18(2), 280-291.

Zafar, S. M. T., Choubey, D. S. \& Khalid, S. M. (2012), “A Study on Dividend Policy and Its Impact on the Shareholders' Wealth in Selected Banking Companies in India". International Journal of Financial Management, 2(3), 79-94. 